\title{
İmam-Hatip Lisesi 9. Sınıf Öğrencilerinin Arapça Yazma Becerileri Kazanımlarını Edinme Düzeylerinin İncelenmesi
}

\author{
Gürkan DAĞBAŞI*
}

\begin{abstract}
$\ddot{O} \mathbf{z}$
Yazma becerisi yabancı dil öğretiminin dört sacayağından biridir ve genellikle bu ayakların dördüncüsü olarak kabul edilir. Bu dört becerinin birbiriyle paralel yürümesi ise dil öğretiminde en istenilen durumdur. Yazma becerisi, dinleme, okuma ve konuşma becerileriyle iç içe geçmiş ve edinilmesi zor olan bir beceridir. Ancak ayrıntılı planlanmış, öğrencilerin seviyesine, yaşına ve ilgisine uygun seçilmiş etkinliklerle yazma becerisinin öğrencilere kazandırılması sanıldı̆̆ı kadar zor değildir. Bu araştırma; yabancı dil olarak Arapça öğrenen öğrencilerin Milli Ĕgitim Bakanlığınca hazırlanan öğretim programında yer alan yazma becerileri kazanımlarını ne derece edindiklerini ortaya koymayı amaçlayan nitel bir çalışmadır. Araştırmanın başlangıcında yabancı dil olarak Arapça öğrenen ve daha önce Arapça geçmişi olmayan 9. sınıf seviyesindeki 70 İmam-Hatip lisesi öğrencisine öğretim programında yer alan yazma becerisi kazanımlarına göre hazırlanan bir sınav uygulanmış ve ardından değerlendirilmiştir. Daha sonra bu sınav sonucuna göre öğrencilerin yazma becerilerine dair birtakım çıkarımlar yapılmıştır. Çalışmanın sonuç bölümünde yazma becerisinin geliştirilmesine yönelik program geliştiricilerine ve öğretmenlere yönelik bazı önerilerde bulunulmuştur.
\end{abstract}

Anahtar Kelimeler: Arapça, yazma becerisi, yabancı dil öğretimi, kazanım, imam-hatip lisesi.

* Dr. Öğr. Üyesi, Çankırı Karatekin Üniversitesi Edebiyat Fakültesi, Arap Dili ve Edebiyatı Elmek: gurkandagbasi@hotmail.com 


\title{
Examination of 9th Grade Imam-Hatip High School Students' Levels of Arabic Writing Skills Acquisitions
}

\begin{abstract}
Writing skill is one of the four trivets of foreign language instruction and generally accepted as the fourth trivet. Performing these four skills together is the most required situation in language instruction. Writing skill is a skill that is interlocked with listening, reading and speaking skills and difficult to obtain. However, it is not to provide writing skills to students is not very difficult with activities that are planned in detail and chosen in accordance with students' level, age and interests. This study is a qualitative study that aims to present to what extent students who learn Arabic as the foreign language have obtained the writing skills included in the curriculum prepared by the Ministry of National Education. At the beginning of the study, an examination that was prepared according to writing skills learning outcomes included in the curriculum was applied on 70 9th grade-Imam Hatip High School students who learn Arabic as a foreign language and have no Arabic background and afterwards it was evaluated. Thereafter, inferences were made with regard to student's writing skills according to the exam results. In the conclusion section of the study, a number of suggestions were given towards teachers and program developing for writing skills.
\end{abstract}

Keywords: Arabic, foreign language teaching, writing skills, learning outcomes, Imam Hatip High School 


\section{Giriş}

Yabanc1 dil öğretimi, dört temel beceri olan dinleme, konuşma, okuma ve yazma becerileri üzerine temellendirilmiştir. Bir dile tam anlamıla hâkimiyet, bu dört beceriye hâkim olmaktır. Dilin öğrenim-öğretim amacı, hedeflere ve kişilere göre değişebilir ve buna bağlı olarak bazı dil becerileri, diğer becerilerin önüne geçebilir. Ancak asıl olan dört temel becerinin birbirlerine paralel şekilde gelişim göstermesidir.

Ahmet Vefa Temel ise (2015: 168), dil öğretiminde her zaman dinleme, konuşma, okuma ve yazma becerilerinin takip edilmesinin pek de mümkün olmadığını, bu becerilerin kullanma sıklığının yabancı dil öğrenme amacıyla paralel gittiğini vurgulamaktadır. Temel'in bu görüşüne katılmak mümkündür çünkü kişinin hedefine göre ağırlık vereceği bir dil becerisi diğerlerinin önüne geçebilir.

Demirel'in belirttiğine göre, birçok kaynakta, dil öğretimi becerilerinin son halkası kabul edilen yazma becerisinin geliştirilmesi de sona bırakılmaktadır. Çoğu yabancı dil öğretmeni yazmayı sınıf içi bir etkinlikten ziyade ev ödevi bağlamında yapılacak bir etkinlik olarak görmektedir. Oysaki yazma becerisi en az konuşma becerisi kadar önemlidir. Dili, kurallarını kullanarak bir mesajı yazılı olarak doğru şekilde ifade edebilmek de çok önemlidir. Bu sebeple, yazma becerisi mekanik bir süreç olarak değil; eleştirel bir düşünme süreci olarak değerlendirilmedir (Demirel 2004: 109). Yazma becerisi öğretiminin sona bırakılma sebeplerinden biri yabancı dil öğretiminin ana dili öğretimine benzetilmesidir. Yani kişi, önce dinler, sonra konuşur en sonda okur ve yazar. Ancak daha önce de geçtiği gibi bu sıralama her zaman bu şekilde olmayabilir; daha da önce de belirtildiği gibi kişilerin veya programların hedefine göre bir beceri diğerlerinin önüne geçebilir.

İsmail Çakır, "Yazma Becerisinin Kazanılması Yabancı Dil Öğretiminde Neden Zordur" başlıklı makalesinde (2010: 166), genellikle öğrencilerin dört dil becerisi içinde en zor beceri olarak yazmayı beyan ettiklerini bunun sebebi olarak 
da öğretmen beklentisinin net olmadığını dile getirdiklerini belirtmektedir. Oysa, yazma becerisiyle ilgili olarak öğretmenlerin hataya düştükleri konu, öğrencilerden yardım almaksızın hatasız ve eksiksiz kompozisyonlar beklemeleridir. Çakır, yaptığ1 araştırmada öğrencilerin \%81'inin yazma becerisini en zor beceri olarak tanımladıklarını, anadilde yazma alışkanlığı olmayan öğrencilerin yabancı dilde de yazmaktan hoşlanmadığını ya da zorlandıklarını belirtmektedir.

Yazma becerisinin öğrencilere kazandırılmasında en önemli öğe hevestir. Öğrencide bu hevesin oluşturulması için; öğrenciye kendine güvenmesi fikri aşılanmalı, öğrencinin düşünmesine katkı sağlanmalı, yazma etkinliği esnasında karşılaştığı güçlüklere yardımcı olunmalı, öğrencilerin faydalanabilecekleri yardımcı kaynaklar hususunda rehberlik edilmeli, öğrenci yazılarında olumsuz taraflardan ziyade olumlu taraflar öne çıkarılmalı ve yüreklendirilmeli, seçilen yazma konuları öğrencilerin hoşuna gidenlerden olmalıdır (Temel 2015: 172). Ancak, Temel'in vurguladığı gibi olumsuz taraflardan ziyade olumlu taraflar öne çıkarılırken, öğrenciler tarafından yapılan dilbilgisel veya yazımsal hatalar göz ardı edilmemelidir. Ayrıca öğrencilerin hoşlarına gidecek konuların yanında günlük/ akademik hayatlarında öğrencilerin işlerine yarayacak yazma konuları da seçilmelidir.

Yazma becerisi; öğrenme sürecini kontrol etmeye, öğrenilen yapıların ve sözcüklerin pekiştirilmesine, öğrenci seviyesinin belirlenmesine, dil yanlışların tespit edilmesine, noktalama işaretlerinin öğretilmesine, dil yetisinin gelişmesine, öğrencilerin yaratıcı düşünmelerine, kelime bilgisinin artmasına, hedef kültürün tanınmasına, öğrenilen bilgilerin kısa süreli bellekten uzun süreli belleğe aktarılmasına katkı sağlamaktadır (Çakır 2010: 168).

Yazmanın en çok zaman alan ve geliştirilmesi en zor olan beceri olduğunu belirten İlter (2014:38), yazma öğretiminin etkin bir şekilde yapılabilmesi için ve öğrencilerin istenilen seviyeye çıkabilmesi için, öncelikli olarak diğer üç dil becerisi olan dinleme, konuşma ve okuma becerileri öğretim süreçlerinin doğru şekilde planlanıp uygulanmasının gerektiğini dile getirmektedir. Eğer bu süreç içinde öğrenci hazır değilse, öğretmen süreci olumlu şekilde yönetememişse ya da uygun materyal kullanmamışsa yazma becerileri süreci olumsuz etkilenecektir. 
Tiryaki (2013: 39) yabancı dil öğretiminde yazma becerisini geliştirirken yazma eğitimi verilecek hedef kitlenin yaş, ana dil, kültür vb özelliklerinin mutlaka göz önünde bulundurulmasını gerektiğini ve öğretmenin yazma sürecinin tamamına hakim, rehber kişi olması gerektiğini belirtmektedir.

Şimşek'e göre, yazma becerisi aslında bir üretim becerisidir. Okuma ve dinleme becerisi ise daha ziyade bir tüketim becerisidir. Dilin üretimi ve anlaş1lması ile ilgili zihinsel tüketim düşünüldüğünde üretimin tüketimden daha zor olduğu barizdir (2017: 241). Bu görüşe katılmak mümkündür çünkü öğrenciler okuma ve dinleme becerisinde genelde kendileri tarafindan oluşturulmayan metinler üzerine yoğunlaşırken; yazma ve konuşmada kendilerinden bir şeyler üretirler ve daha aktiftirler.

\section{Arapça Yazma Becerisi Öğretimi}

Usta'ya göre yazma becerisi, dil becerileri içinde en önemlisidir ve Arapça öğretiminin de son halkasıdır. Yazmayı sadece bir dilsel beceri olarak düşünmek de eksikliktir. Çünkü yazma, iletişim aracı olmasının ötesinde, toplumların hayatlarında özel bir konuma sahiptir. İnsanlık, kültür ve medeniyet varlıklarını kaybolmaktan yazı ile koruduğu gibi, sonraki nesillere de aktarma da yine tek alternatif olarak yazıyı kullanacaktır (2012: 324). Ancak Usta'nın bu görüşüne tamamen katılmak mümkün değildir. Çünkü dil öğretimi bir bütündür ve bu sebeple okuma, yazma, konuşma ve dinleme becerilerinden her hangi biri için " bu beceri dil öğretiminde en önemli beceridir” demek çok iddialıdır ve doğru değildir. Elbette, bireylerin ya da kurumların ihtiyaçlarına göre bazen bir beceri öne çıkabilir ancak bu becerinin yazma olduğu ve önemli beceri olduğu anlamına gelmez.

Doğan (1989:186) yazının, konuşularak ifade edilenlerin özel yazı sembolleriyle şekillendirilmiş biçimi olan görsel bir etkinlik olduğunu, diğer dil becerilerinden ayrı düşünülemeyen yazma becerisinin özellikle de okuma becerisiyle birbirinden ayrılamayacağını ve bu iki becerinin birbirini tamamladığını vurgulamaktadır. Yazı, otomatik kas hareketleriyle birlikte ses ve sembol arasındaki ilişkinin güçlenerek ortak melek oluşmasıyla öğrenilir. Bundan dolayı Arapça yazmaya geçmeden önce öğrenciler şu becerileri edinmiş olmalıdır: 
1- Öğrenciler, Arapçadaki tüm harfleri ses ve sembolleriyle birbirinden ayırt etme becerisini kazanmış olmalıdır.

2- Öğrenciler, yazacakları sesleri doğru telaffuz etme becerisini kazanmış olmalıdır.

3- Öğrenciler, yazacakları harflerin seslerini bilme becerisini kazanmış olmalıdır.

4- Öğrenciler, duydukları seslerin harf şekillerini yazma becerisini kazanmış olmalıdır.

5- Öğrenciler, duydukları sesleri harf sembollerine dönüştürme becerisini kazanmış olmalıdır.

el-Hûli de (2000: 104-114), Arapça yazma becerisi öğretiminde şu sıranın takip edilmesi önermektedir:

1- Harflerden önce: $\mathrm{Bu}$ aşamada, öğrenciye kalemi nasıl tutacağı, harflerin yazımında kullanılacak çizgilerin boyutu, dikey veya yatay olma durumları öğretilir.

2- Harflerin yazımı: Öğrencilere harflerin nasıl yazıldığı, boyutları, noktaları vb gibi özellikler gösterilir. Bu aşamada harflerin bitişik şekillerinden ziyade aralıklı yazılışları gösterilmelidir. Harflerin bilinen alfabetik sıralamaya göre yazılması, öğrencilerin harfleri yazmadan önce öğretmenlerinin el hareketleri dikkatlice gözlemlemesi de önemlidir.

3- Bakarak yazma: Harflerin bitişik ve ayrı yazılışları öğrencilere kavratıldıktan sonra öğrencilerden ders kitabında yer alan bazı kelime ve cümleleri bakarak defterlerine yazmaları istenir. Bakarak yazmanın, noktalama işaretlerinin kavratılmasına, öğrenilen kelime ve kalıpların pekiştirilmesine, doğru okuma duygusunun geliştirilmesine, yazının güzelleşmesine katkı sağlayacağı açıktır.

4- Dikte: Dikte aslında genel ifadeyle, öğrencilerin duyduklarını yazabilme yeteneğinin yoklandığı aşamadır. Dikte genelde, öğrencilerin aşina oldukları kelime ve kalıplarla yapılır. Seçilen kelimelerin, cümlelerin veya paragrafin da diktesi yaptır1labilir. 
5- Bağımlı Yazma: Paralel cümleler, paralel paragraf, cümleyi dönüştürme, cümle tamamlama gibi birçok şekilde uygulanabilen bağımlı yazma, öğrenilen bilgilerin yeni durumlara uygulanmasıdır.

6- Bağımsız Yazma: Yazma becerisinin son aşamasıdır. Öğrenciler, öykünmeli, betimsel, önermeli, tartışmalı gibi konulardan biri hakkında daha önceki bilgilerini organize ederek duygu, düşünce ve fikirlerini yazılı olarak ifade ederler.

Doğan'a göre diğer dillerde olduğu gibi Arapça öğretimine de doğru anlama, konuşma, okuma ve yazmaya karşı bir alaka ve heves uyandırarak başlanmalı ve bunlar her aşamada gerçekleştirilecek hedefler olarak göz önünde bulundurulmalıdır (2000: 166). Ancak ihtiyaçlara göre Doğan’ın dil öğretimi için önerdiği sıralamanın değişebileceği göz ardı edilmemelidir.

Temel (2015: 170), Türk öğrencilerin Arapçayla ilk karşılaştıklarında bir takım zorluklar yaşadıklarını ancak zaman ilerledikçe bu sıkıntıların ortadan kalktığını vurgulamaktadır.

Arap alfabesi Türkçeden farklıdır. Her harfin başta-sonda-ortada olmak üzere üç farklı biçiminin bulunur. Türkçenin aksine sağdan sola yazılır. Bitişen ve bitişmeyen harfler olarak ayrılır. Büyük-küçük harf ayrımı yoktur ve ünlü harfleri yoktur. Arapçada cümle kurulumu Türkçeden farklıdır (Türkçede özne-nesneyüklem iken Arapçada yüklem-özne-nesne). Bu saydığımız durumlar Arapçayı öğrenenlerin ilk aşamada karşılaştıkları ve Temel'in de belirttiği yazma becerisine dair zorluklardan bazılarıdır. Bu zorlukların aşılması için de öğrencilere hedef ile ana dil arasındaki farklılıklar veya benzerlikler ayrıntılı ve net bir şeklide anlatılmalıdir.

\section{Arapça Öğretim Programına Dair}

Milli Eğitim Bakanlığı tarafından hazırlanan 9-12. sınıflar ikinci yabancı dil olarak Arapça öğretim programı da bu durumu temel almıştır. Ortaöğretim Arapça dersi öğretim programı yabancı dil olarak Arapça okutacak okullar için hazırlanmıştır. Bu sebeple, Arapçayla ilk kez tanışacak öğrencilerin seviyeleri göz önünde bulundurmuştur. Programda tümevarım yöntemi benimsenmiş; öğretim özelden genele, somuttan soyuta, kolaydan zora doğru tasarlanmıştır. Demir'in 
de belirttiği gibi (2015: 88) Milli Eğitim Bakanlığınca hazırlanan Arapça dersi öğretim programı dilin kurallarına yoğunlaşmak yerine, bir iletişim aracı olarak kullanımına önem vermektedir.

Programın kendi içinde önce çıkan bir yönü de sarmal yaklaşımı benimsemiş olması ve programın oluşturulmasında Diller İçin Avrupa Ortak Başvuru Metninden faydalanılmasıdır. Dört temel dil becerisi paralel yürüyecek şekilde tasarlanan programda, yazma becerilerine harflerin öğretim ile başlanması planlanmıştır. Alfabetik sıranın bağlayıcı olmadığı belirtilip, yazma öğretimi başlangıcında anlamlı kelimelerin ve ilerleyen aşamalarda da temaya uygun yapıların verilmesi istenmiştir. Öğretmenin motive edici rolüne, yol göstericiliğine, öğrencilerin kendi hatalarını düzeltmeleri için fırsat verilmesi gerekliliğine vurgu yapılmıştır.

Kazanım, öğrenciler için eğitim yoluyla programlı ve planlı bir öğretmeöğrenme süreci sonunda ulaşılması beklenen tutum, bilgi, beceri ve değerlerin tamamıdır. Bundan dolayı, öğrencilerin dil becerilerindeki gelişimleri programda belirlenen kazanımların ne derece edinildiğine bağlıdır. Programın 9.sınıflar Arapça dersi için hazırlanan kısmında toplam 80 kazanım vardır. 80 kazamın edinilmesi için 4 tema belirlenmiş ve bu temaların 72 ders saati içinde işlenmesi planlanmıştır. Çalışmamıza konu olan yazma becerileri kazanım sayısı ise 20'dir (Komisyon 2017:3-13).

Araştırmanın Amacı: Bu araştırmanın amacı, yabancı dil olarak Arapça öğrenen 9. sınıf öğrencilerin, Mili Eğitim Bakanlığınca hazırlanan öğretim programında yer alan yazma becerileri kazanımlarını ne ölçüde edindiklerini belirlemek ve yazma becerisinin geliştirilmesine yönelik program geliştiricilere ve öğretmenlere bazı önerilerde bulunmaktır.

Araştırmanın Yöntemi: Bu araştırmada nitel araştırma yöntemi kullanılmıştır. Araştırma kapsamında, yabancı dil olarak Arapça öğrenen Çankırı Hacı Murad-i Veli Anadolu İmam-Hatip Lisesi 9. sınıfta öğrenim gören ve daha önce Arapça geçmişleri olmayan toplam 70 öğrenciye yazma kazanımlarını içeren bir sınav uygulanmıştır. Bu öğrenciler haftada 2 ders saati olmak üzere bir eğitim-öğretim yılı boyunca 72 ders saati Arapça dersi görmüşlerdir. Çalışmaya konu olan 
sınav, 72 saatlik ders saatinin bitiminde uygulanmıştır. MEB tarafından hazırlanan öğretim programı gereğince Arapça dersinde her hangi bir dil becerisi için özel bir zaman dilimi ayrılmamıştır. Yani dört dil becerisinin 72 ders saati içinde bir bütün olarak işlenmesi planlanmıştır. Ayrıca sınav hazırlanırken iki Arapça öğretmeninin de görüşleri alınmıştır.

Verilerin Analizi: 70 öğrenci tarafindan cevaplanan sorular araştırmacı tarafından okunduktan sonra, bir Arapça öğretmeni tarafından da değerlendirilmiştir.

Bulgular ve Yorum: Öğretim programında 9. Sınıf yazma becerilerine dair yirmi kazanım yer almaktadır. Ancak bazı kazanımlar birbiriyle aynı olduğundan tek kazanım başlığında birleştirilmiş, değerlendirme ve yorumlar on beş kazanım üstünden yapılmıştır.

Bu sınav için seçilen soru türleri ile kelime ve cümleler, Milli Eğitim Bakanlığı tarafından hazırlanan 9-12. sınıflar ikinci yabancı dil olarak Arapça öğretim programından alınmıştır.

Kazanım 1 :Arapçanın seslerini ortografik şekilleriyle yazar.

Soru : Duyduğunuz harfleri yazınız.

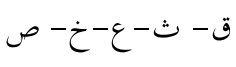

Soru : : Verilen harfleri birleştiriniz.

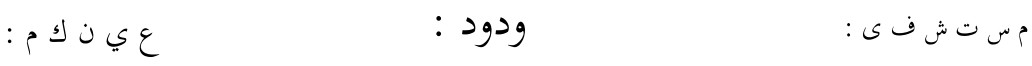

Bu kazanımı ölçmek için iki soru sorulmuştur. Birinci soruda öğrencilerden yüksek sesle üç kez tekrarlanan harfleri yazmaları istenmiştir. 70 öğrenciden

66'sı tüm harfleri doğru yazarken 4 öğrenci hata yapmıştır. Hata yapılan harf daha ziyade `’' dir. Kazanımın gerçekleşme yüzdesi 94.28'dir. Diğer soruda ise öğrencilerin harflerin başta-ortada-sonda hallerini bilip bilmedikleri ölçülmüştür.

70 öğrenciden 65 'i tüm harfleri doğru birleştirmiştir. Kazanımın gerçekleşme yüzdesi 92.85 'dir. Hata yapan 5 öğrenci ise bitişmeyen harfleri bitiştirmiş ve harflerin ortadaki yazılışını yanlış yapmıştır.

Kazanım 2 :Basit ifade ve cümleleri gördüğü şekliyle yazar. 
Soru

kâğıdınıza yazınız.

هي قادمة من المدرسة
:Tahtada yazılı cümle veya ifadeleri 1 dakika içinde

Bu kazanımı ölçmek için bazı cümle ve ifadeler tahtaya yazılmış ve öğrencilere bakarak yazmaları için 1 dakika süre verilmiştir. 70 öğrenciden $65^{\prime}$ i tahtadakilerin hepsini doğru yazarken 5 öğrenci bir cümleyi tamamlayamamıştır. Kazanımın gerçekleşme yüzdesi $92.85^{\prime}$ 'dir.

Kazanım 3 :Dikte çalışması yapar.

Soru :Duyduğunuz cümleleri harekeleriyle birlikte yazınız.

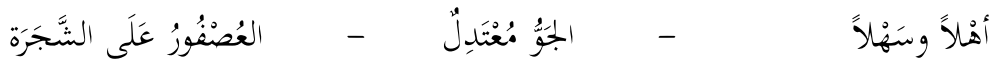

Yukarıda verilen üç cümle, öğrencilere ikişer kere yavaş hızda okunmuş ve öğrencilerden duydukları bu cümleleri yazmaları istenmiştir. 70 öğrenciden 60’1 tüm cümleleri doğru yazarken 10 öğrenci çeşitli yazma hataları yapmıştır. Bu hatalardan en yayın olanı ise أهْاً, وسَهْهاً yazarken bazı öğrencilerin "tenvin” kullanmak yerine kelimelerin sonuna "nun” harfi ekleyip أهْلنْ وسَهْلْنْ و yazmasıdır. Ayrıca iki

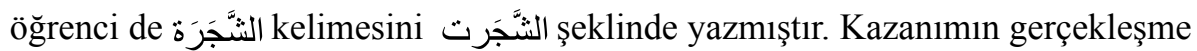
yüzdesi ise 85.38 ' dir.

Kazanım 4 :Yazılarında söz öbeklerini bağlamada "g" bağlacını kullanır.

Soru :Verilen kelimeleri anlamlı bir cümle oluşturacak şekilde yazınız.

$$
\text { أمي - أبي - البيت - و - }
$$

Öğrencilerden verilen kelimeleri sıralamaları istenmiştir. Burada amaç öğrencinin ve bağlacını yerinde kullanıp kullanamadığını ölçmektir. 70 öğrenciden 62'si doğru sıralamayı yaparken 8 öğrenci çeşitli hatalar yapmıştır. Kazanımın gerçekleşme yüzdesi 88.57'dir.

Kazanım 5 :Konuyla ilgili basit sorulara cevap verir.

Soru :Verilen sorulara cevaplar yazınız. 
من أين أنت؟

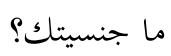

ما اسمك؟

Öğrencilere, öğrendikleri temaya uygun, tanışmaya yönelik 3 soru sorulmuştur. 70 öğrenciden 67'si tüm soruları doğru cevaplarken üç öğrenci من جنسيتك sorusuna cevap verememiştir. Kazanımın gerçekleşme yüzdesi 96.23'dür. Kazanımın gerçekleşme oranı yüksektir.

Kazanım 6 :Aile, arkadaşlar, akrabalar konusuyla ilgili kısa yazılı sorular sorar.

Soru :Arkadaşınızı tanımaya yönelik üç soru yazınız.

Bu kazanımda öğrencilerden ما اسمك؟ - sن أين أنت؟ gibi basit sorular yazması beklenmiştir. 70 öğrenciden 63'ü üç soruyu da eksiksiz yazarken 7 öğrenci 2 soru yazmıştır. Kazanımın gerçekleşme düzeyi \%89.46’dır.

Kazanım 7 :Aile, arkadaşlar, akrabalar konusuyla ilgili kısa yazılı sorulara cevaplar verir.

Soru : : $\quad$ :şağıdaki soruları cevaplayını.

$$
\text { ما ما مهنة والدك؟ }
$$

Verilen soruların cevaplanma yüzdesi 83.78 'dir. 11 öğrenci ise üç sorudan en az birine cevap verememiştir. "Dedenin ismi ne" sorusu en çok doğru cevaplanan sorudur, muhtemelen "isim" kelimesinin Türkçede bulunması ve "meslek" kelimesine göre daha hatırlanabilir olması, bu sorunun cevaplanma yüzdesini en yukarıya taşımıştır.

Kazanım 8 :Kısa ifadelerle ailesini ve akrabalarını yazılı olarak betimler.

\section{Soru} :Ailenizi ve akrabalarınızı kısa cümlelerle tanıtınız.

Bu soruda, öğrencilerden خالي تاجر ماهر- نحن أسرة كبيرة gibi cümleler kurması beklenmiştir. Öğrencilerden 58'i kazanımı karşılayacak düzeyde cümle 
yazmıştır ve bu da \%82.36 oranına denk gelmektedir. Göze çarpan hususlardan biri, mubteda-haber uyumunun bazı öğrencilerin zihinlerinde oturmamış olduğudur. Geriye kalan 12 öğrenciden 2'si soruyu boş bırakırken; 10 öğrenci bir-iki cümle yazmakla yetinmiştir.

Kazanım 9 :Karşılaştığı sayıları yazar.

Soru : :Verilen sayıların karşılıklarını yazınız.

$1:$

Öğretim programına göre öğrenciler 1-10 arasındaki sayıları öğrenmişlerdir. Öğrencilerden sayıların kullanımına dair bir performans sergilemeleri beklenmemektedir. Bu yüzden bu soruda üç sayı verilmiş ve öğrencilerden sayıların karşılarına Arapçalarını yazmaları istenmiştir. 61 öğrenci tüm sayıları doğru yazmıştır, 9 öğrenciden bazıları "üç" sayısını yazarken "peltek se" yerine "normal se (sin)" yazmıştır; bazıları ise bir sayısındaki uzatmayı yazmamıştır. Kazanımın gerçekleşme düzeyi de 86,62 olmuştur.

Kazanım 10 :Temel noktalama işaretlerini bilir.

Soru

:Verilen boşluğa uygun noktalama işaretini koyunuz.

$$
\begin{aligned}
& \text { الكتاب ( ) الدفتر على الطاولة } \\
& \text { والديّ مهندسة ماهرة ( ) } \\
& \text { هل هو عمك ( ) }
\end{aligned}
$$

Öğretim programı çerçevesinde öğrencilerden verilen boşluklara sırasıyla virgül, nokta ve soru işareti koymaları beklenmiştir. Virgülü doğru koyan öğrenci oranı \% 95,6 noktayı doğru koyan öğrenci oranı \% 100, soru işaretini doğru koyanların oranı ise \% 88.04'dür. En çok yanlışın yapıldığı soru işaretinde, 8 öğrenci cümleyi noktayı ile tamamlamıştır. Muhtemelen bu öğrenciler s soru edatını gözden kaçırıp cümleyi düz cümle sanmışlardır.

Kazanım 11 :Metin veya diyalogla ilgili sorulara cevaplar verirler.

Soru : :Verilen soruları diyaloga göre cevaplayınız. 


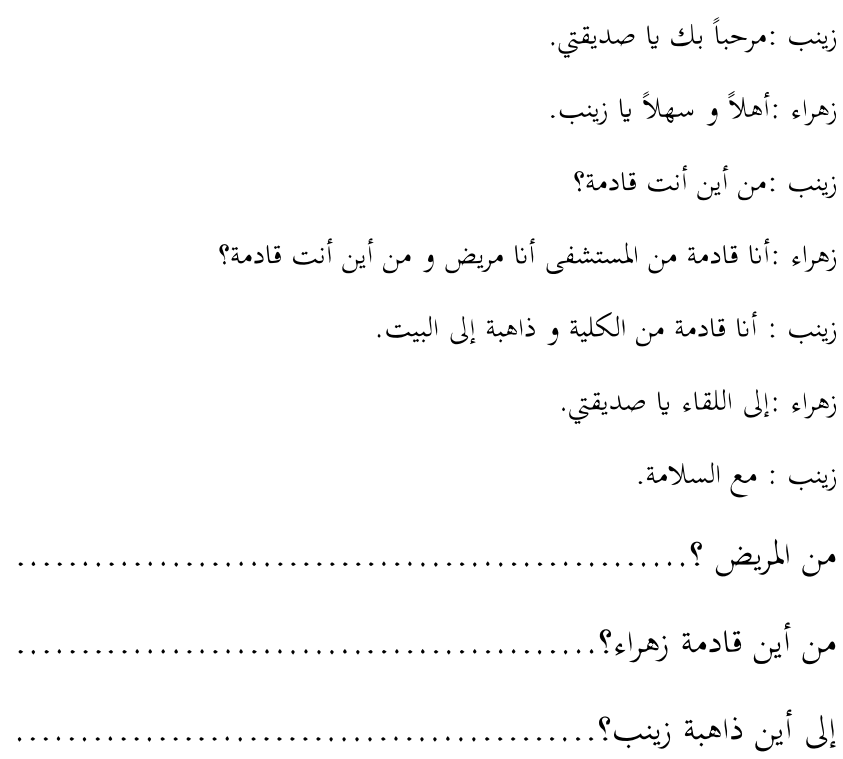

Diyalog, öğrencilerin daha önce işledikleri temaya uygun seçilmiştir. Kazanımın gerçekleşme düzeyi yüzde 80,94'tür. 70 öğrenciden 57'si tüm sorulara doğru cevap vermiştir. Diğer 13 öğrencinin cevaplarında ise bir takım gramer yanlışları vardır. Bazı öğrenciler, sorularının cevaplarını diyalogdan aynen olduğu gibi kopyala-yapıştır yapmıştır. "Kim hasta” sorusuna diyalogda geçer haliyle "Ben hastayım”, "Zeynep nereye gidiyor” sorusuna "ben eve gidiyorum” cevaplarını vermişlerdir.

Kazanım 12 :Basit tablo ve grafikler hazırlar.

Soru :Haftanın günlerini basit bir tablo halinde yazınız.

53 öğrenci bu soruya cevaplamıştır. 12 öğrenci ise tabloyu bazı kısımlarını doldurmuş, 5 öğrenci ise soruyu boş bırakmıştır. Kazanımın gerçekleşme düzeyi 75,26 'dır. Bu soruyu eksiksiz yazabilmek için haftanın günlerinin bilinmesi gerektiği barizdir. Bu soru göstermiştir ki yaklaşı $\% 25$ oranından bir öğrenci grubu haftanın günlerini eksiksiz bilmemektedir.

Kazanım 13 :Tercih ve beğenilerini yazılı olarak ifade ederler.

Soru : Verilen kelimeleri birer cümlede kullanınız. 
52 öğrenci istenilen şekilde cümle oluşturmuştur, 18 öğrenciden bazıları da bir cümleyi doğru yazmıştır, bazı öğrenciler ise soruya uydurma cevaplar vermiştir. Bu kazanımın gerçekleşme oranı \% 73.84'dür. Sorunun doğru cevaplanması verilen kelimelerin "tercih ederim" ve "sevmem” anlamlarına geldiğini bilmekle doğrudan orantılıdır. Yanlış cevap verenlerin bu anlamları bilmediği kanısına ulaşmak mümkündür. Ayrıca öğrencilere cümlede kullanmaları için verilen kelimeler rast gele seçilmemiştir, öğretim programından alınmıştır.

Kazanım 14 :Yazı çalışmalarında sayısal ifadeler kullanır.

Soru : İçinde sayma ya da sıra sayısı geçen bir cümle veya ifade yazınız.

Öğrenciler, öğretim programı kapsamında 1-10 arası sayma sayıları ile sıra sayılarını öğrenmişlerdir. Yazılarında bunlardan birini kullanmaları gibi ifadeler yazmaları beklenmiştir. 70 öğrenciden 62'si kazanımı karşılayan cevap yazmıştır ve kazanımın gerçekleşme oranı \% 88,04 olmuştur. Öğrenci cevaplarından en çok geçen say1 و احد olmuştur. Muhtemelen öğrencilere yazması veya akılda tutması en kolay gelen sayı budur.

Kazanım 15 :Yazı çalışmalarında zaman ifadelerini kullanır.

Soru

: Verilen kelimeleri birer cümlede kullanınız.

$$
\text { ظهراً: }
$$

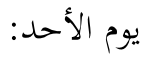

Kazanımın gerçekleşme oranı \% 71 'dir ve bu da 50 öğrenciye denk gelmektedir. 20 öğrenciden 6'sı ise bir kelimeyi cümlede kullanmıştır. Tüm sorular içinde cevaplanma oranı en düşük olan soru budur. Hem kelimenin anlamını bilmeyi hem de anlamlı bir cümle kurmayı gerektirdiği için diğer sorulara göre öğrencilere biraz zor gelmiş olabilir.

\section{Sonuç}

Yabancı dil öğretimi, çoğu zaman birbiriyle iç içe geçmiş dinleme, konuşma, okuma ve yazma becerilerinden oluşan bir bütündür. Yazma da bu dört 
beceri içinde son halka olarak kabul edilen ve genelde de edinilmesi en zor olan beceridir. Ancak zor olması demek edinilemeyeceğini anlamına gelmemektedir. Öğretmen tarafından, öğretim programının hedeflerine ve kazanımlara göre hazırlanmış etkinlikler ve materyallerle desteklenmiş bir süreçte, yazma becerilerinin istenilen seviyeye getirilmesi gayet olasıdır.

Arapçada sesli harflerin olmayışı, her harfin üç farklı forma sahip olması, sağdan sola yazılması, cümle kurulumun Türkçeden farklı olması Arapçayla ilk kez karşılaşan öğrencilere ilk başta zor gelse de, zamanla bu zorluk aşılmaktadır. Milli Eğitim Bakanlığınca hazırlanan, yabancı dil olarak Arapça öğretiminin adeta yol haritası olan öğretim programında 9.sınıf öğrencileri için seksen kazanım yer almaktadır ve bunlardan yirmisi yazma becerileriyle ilgilidir. Çankırı ilindeki İmam-Hatip Lisesinde öğrenim gören ve Arapçayla ilk kez karşıllaşan yetmiş öğrenciye uygulanan yazma becerileri değerlendirme sınavına göre kazanımların genel edinim oranı yaklaşık \%85' dir. Bu oranın \%100'e yakın olması en ideal olsa da \%85 de gayet yüksek bir orandır. Bu sonuç öğretim programında belirtilen kazanımların büyük ölçüde edinildiğinin ve aynı zamanda bakanlıkça hazırlanan programın öğrencilerin seviyesine uygun olduğunun göstergesidir. 9.sınıf öğrencilerin en başarılı oldukları yazma kazanımları: konuyla ilgili sorulara cevap yazma, noktalama işaretlerini kullanma, sayıları yazılı olarak ifade etme iken; en başarısız oldukları yazma kazanımları: zaman ifadelerinin yazı çalışmalarında kullanılması, tercih-beğenilerini yazılı olarak ifade etme ve grafik-tablo hazırlamaktır. Bu başarısızlığın sebepleri arasında yazma becerilerine dair alıştırmalar için ders kitabında yeterli etkilik olmaması ve 72 ders saati içinde öğrencilerden 9. sınıf Arapça dersine ait 80 kazanımı edinmelerin beklenmesi gösterilebilir. Çünkü öğrencilerden her ders saatinde ortama 1,11 kazanım edinmeleri beklenmektedir ki bu oran yüksektir. Genelde Arapça özel de Arapça yazma becerilerin geliştirilmesi için haftalık ders saatinin artırılması ya da kazanım sayısının azaltılması yerinde bir karar olabilir.

Ayrıca başarılı bir dil öğretim süreninin gerçekleşip gerçekleşmediğini belirleyebilmek adına Milli Eğitim Bakanlığınca tüm ülkeyi kapsayan, dört temel dil becerisini ölçen sınavlar yapması ülke çapında hangi kazanımların yeterli de- 
rece edinildiğini ya da hangi konularda eksikler olduğunu göstermede önemli veriler sağlayacaktır. Bu verilerden hareketle de gerek ders içerikleri gerek öğretim yöntem ve teknikleri gibi konularda düzeltmeler yapılabilir.

Bütün bunlara ek olarak yabancı dil öğretmenlerinin dört temel beceriyi etkin bir şekilde öğretebilecek donanıma sahip olmaları, öğretim materyallerinin çeşitlendirilmesi, öğrencilere yaratıcı ortamlar sağlanması, daha önce yapılan bilimsel çalışmalardan yararlanarak öğrencilerin zorlanmaları olası konu ve kazanımların önceden tahmin edilip öğretim sürecinin buna göre planlanması yabanc1 dil öğretiminde hedeflere ulaşılmasında önemli rol oynayacaktır. 


\section{Kaynakça}

Çakır, İ. (2010). Yazma Becerisinin Kazanılması Yabancı Dil Öğretiminde Neden Zordur, Erciyes Üniversitesi Sosyal Bilimler Enstitüsü Dergisi, s. 165-176.

Demir, M. (2015). İlköğretim 4. Sınıf Arapça Dersi Öğretim Programına İlişkin Öğretmen Görüşleri, 21. Yüzyılda Eğitim ve Toplum, kış sayısı, s. 85- 99.

Demirel, Ö. (2004). Yabancı Dil Öğretimi, Ankara: Pegem A Yayınları,.

Doğan, C. (1989). Yabancı Dil Olarak Arapça Öğretim Metot ve Teknikleri, Ankara.

Doğan, C. (2000). Yabancı Dil Olarak Arapça Öğretiminde Öğrenim-Öğretim Konusu ve Aracı Olan Dil Orijinli Sorunlar ve Çözüm Yolları, Ekev Akademi Dergisi, kasım sayısı, s. 147-168.

el-Hûli, M. A. (2000). Arapça Öğretim Metotları, çev. Akçay C., Ankara: Bizim Büro Bas1mevi.

Genç İlter, B. (2014). Yabancı Dil Öğretiminde Yazma Becerileri Nasıl Geliştirilebilir, Dil Dergisi, s. 36-45.

Komisyon, (2017). Ortaöğretim İkinci Yabancı Dil Arapça Dersi (9-12. Sinıflar) Öğretim Programi, Ankara.

Özcan, M. (2015). Yabancı Dil Olarak Arapça Konuşma Becerisi Öğretiminde İletişimsel Yaklaşıma Dayalı Etkinliklerin Kullanımı, 21. Yüzyılda Eğitim ve Toplum, bahar sayısı, s. 153- 163.

Şimşek, P. (2017). Anadili Arapça Olan Öğrencilerin Türkçe Yazma Becerileri Öz Değerlendirmeleri, Route Educational and Social Science Journal, v.4, s. 237-248.

Temel, A., V. (2015). Türkiye'de Arapça Öğretiminde Uygulanan Metotlar, Karşılaşılan Sorunlar ve Çözüm Önerileri Üzerine Bir Değerlendirme, Abant İzzet Baysal Üniversitesi Ilahiyat Fakültesi Dergisi, bahar sayısı, s. 166-174.

Tiryaki, E. N. (2013). Yabancı Dil Olarak Türkçe Öğretiminde Yazma Eğitimi, Ana Dili Eğitimi Dergisi, s. 38-44.

Usta, İ. (2012). Dört Temel Dil Becerisi ve Arapça Öğretimindeki Katkıları, The Journal of Akademic Social Science Studies, s. 317-326. 